\title{
293sTE BESTUURSVERGADERING
}

\author{
GEHOUDEN 19 MEI 1888.
}

\begin{abstract}
Tegenwoordig de hh. Kern (Voorzitter), Kielstra (Ondervoorzitter), J. H. de Groot (Penningmeester), Martin, Snouck Hurgronje, Wilken, Niemann, Riedel, Humme en Wijnmalen (Secretaris). Alwezig de hh. Bool en de Roo, met kennisgeving.
\end{abstract}

De notulen van het verhandelde in de vorige vergadering worden gelezen en goedgekeurd.

De Secretaris doet opgave van de sedert de vorige bijeenkomst ontvangen boekwerken, waarna wordt medegedeeld, dat zijn ingekomen :

10. missives van de Directie van de Bibliotheek der gemeenteinrichting ter opleiding van Oost-Indische ambtenaren te Leiden, dd. 26 April jl., van den Conservator van de Bibliotheek van Teyler's stichting te Haarlem, van 25 April jl., en van het Department of the Interior, United States Geological Survey, te Washington, D. C., van 24 April jl., - allen houdende bericht van ontvangst van en dankbetuiging voor de toegezonden $2 \mathrm{e}$ aflevering, derde deel, vijfde volgreeks der Bijdragen van het Instituut.

Voor kennisgeving aangenomen.

20. eene missive van de Directie van de Oberhessische Gesellschaft für Natur- und Heilkunde, te Giessen, dd. 7 Mei jl., houdende verzoek tot ruiling van wederzijdsche uitgaven.

Wordt besloten te antwoorden, dat, daar de Oberhessische Gesellschaft zich op een geheel ander gebied beweegt dan het Instituut, een letterkundig verkeer tusschen de beide Instellingen geen bevredigend resultaat zal opleveren

30. missives van de heeren J. C. Bloem, te 's Gravenhage, en J. G. Plate Jr., te Tueiden, beiden houdende verzoek van de ledenlijst te worden afgevoerd.

Voor kennisgeving aangenomen. 
40. eene missive van den heer E. J. Voute, Directeur van de Nederl. en Ind. Tuinbouw-maatschappij te Zeist, thans tijdelijk te Buitenzorg, houdende mededeeling van de aanvaarding van het lidmaatschap, onder aanteekening dat over de contributie ten kantore der Maatschapkij te Zeist kan worden beschikt.

Voor kennisgeving aangenomen.

Ter tafel worden gebracht brieven van Commissarissen in Indië, dd. 19 Maart jl. no. B/162 en 13 April jl. no. B/167, benevens drie briefkaarten van 23 en 24. Maart en 7 April jl. Commissarissen deelen daarbij meê:

10. dat tot leden van het Instituut zijn toegetreden de hh. mr. J. H. Bergsma, A. H. G. Fokker, M. Willemstijn en H. van Lokhorst te Batavia, Mr. Caesar Voute te Semarang, H. M. Ia Chapelle, te Buitenzorg, J. van Hengel, Controleur $2 \mathrm{e}$ klasse te Indrapoera (Sumatra's Westkust), J. G. Schot, te Fort de Kock, met verzoek aan allen de verschenen edita over het loopend jaar te doen zenden; 20. dat in een aan den heer Nijhoff geadresseerde kist van het Bataviaasch Genootschap met bestemming voor de boekerij van het Instituut eenige boekwerken en kaarten zijn verzonden, waarvan eene lijst wordt bijgevoegd; 30. dat, ingevolge reeds vroeger gedane mededeelingen, pogingen in het werk zijn gesteld om voor de boekerij van het Instituut de prachtige verzameling photographieën door Van Kinsbergen van Javaansche oudheden (andere dan de Boro Boedhoer) vervaardigd, te bekomen: welke pogingen niet te vergeefs zijn geweest, zoodat hoogst waarschijnlijk binnen kort die collectie door de lndische Regeering aan het Instituut zal worden geschonken, terwijl daarentegen andere door particulieren vervaardigde photographieën moeielijk anders dan tegen betaling zouden kunnen worden verkregen. Voor eene tamelijk volledige verzameling zou een bedrag van $f 2000$ nauwelijks voldoende zijn; $-4^{0}$. dat de heer H. M. La Chapelle, in, verband met zijne overplaatsing naar Buitenzorg, er van heeft afgezien een Indisch Lapidarium te bewerken.

De Secrataris wordt gemachtigd Commissarissen, voor zooveel noodig, eenig antwoord te doen toekomen.

De Secretaris deelt den inhoud mede van een door hem van het lid dr. J. Groneman, te Djokdjakarta, ontvangen schrijven, dd. 30 Maart jl. betreffende den voorgenomen of wel het voortzetten van den arbeid der Djokdjasche Vereeniging aan de tempels in de vlakte 
van Parambanan, waaromtrent het Bestuur reeds vroeger eenige mededeelingen mocht ontvangen. Nu de aanvrage om subsidie voor dien arbeid door de Regeering is van de hand gewezen, wordt een beroep gedaan op het Instituut en zijn financieële steun verzosht.

$\mathrm{Na}$ beraadslaging wordt besloten den heer Groneman te berichten, dat door de groote werken, waarvan de uitgave door het Instituut zoowel in dit als in het volgende jaar wordt ondernomen of voorbereid en aanzienlijke kosten vorderi, de staat der kas niet toelaat aan eenige andere onderneming, hoe wenschelijk zij overigens zij, financieëlen steun te verleenen.

Met het oog op de aanstaande verschijning van het werk van Dr. Snouck Hurgronje over Mekka is zoowel met den Schrijver als met den uitgever Nijhoff en de firma Brill in overleg getreden omtrent de samenstelling van een prospectus, dat aan de leden van het Instituut toegezonden en tevens algemeen verspreid kan worden. De Secretaris koestert de hoop dat men daarmeê reeds voor de volgende bijeenkomst zal kunnen gereed komen.

De Secretaris deelt mede dat hij, naar aanleiding van de hem in de vorige vergadering verstrekte machtiging, en den Voorzitter gehoord, met den uitgever M. Nijhoff en de firma Brill in onderhandeling is getreden over de uitgave der Atjehsche taalwerken van den heer van Langen. Het resultaat van het gehouden overleg is geweest, dat men zich bereid heeft verklaard bedoelde taalwerken, en wel de Atjehsche spraakkunst met chrestomathie en het Atjehsche woordenboek uit te geven in twee deelen, in $8^{0}$ formaat, met dien verstande dat, voor zoover het de spraakkunst betreft, deze in haar geheel in proef zal worden geleverd vóór het vertrek des Schrijvers in Juni a. s. De kosten der uitgave van beide deelen worden geraamd op een bedrag van hoogstens $f 2500$.

Naar aanleiding van de gerezen klachten over de verzending der Werken en Bijdragen aan de leden buiten den Haag, wordt door den Secretaris in overweging gegeven haar in het vervolg niet meer te doen plaats hebben door tusschenkomst van den boekhandel, maar de edita den leden, buiten de residentie woonachtig, rechtstreeks over de post te doen toekomen, evenals zulks met het beste gevolg reeds sedert geruimen tijd geschiedt met de expeditie naar Oost- en West-Indië.

Bij de beraadslaging, welke over dit voorstel wordt gevoerd, wordt 